\title{
Връзката между носната обструкция и енурезис ноктурна - описание на клиничен случай и преглед на литературата
}

\author{
П. Генова, Пл. Недев, Г. Илиев, Н. Сапунджиев, \\ М. Милков, Д. Марев, Ал. Трайкоски \\ МУ „Проф. д-р П. Стоянов“ - Варна \\ Клиника по УНГ-болести при МБАЛ „Света Марина“ - Варна
}

\begin{abstract}
Резюме
Представяме клиничен случай на 20-годишен пациент с енурезис ноктурна и носна обструкция, дължаща се на девиация на носната преграда, който беше опериран в нашата клиника. След направената септопластика в продължение на деветмесечно наблюдение са преустановени напълно нощните напикавания на пациента. Известна и описана в литературата е връзката между първичната енурезис ноктурна и обструктивната сънна апнея при децата - сънната апнея е често срещана при децата с нощно напикаване и първичното нощно напикаване е чест симптом на такъв обструктивен синдром. Липсват категорични данни за връзката между изолираното нарушено носно дишане без сънна апнея и първичната енурезис ноктурна. Обсъждане на ролята на носната обструкция при случаите на нощно напикаване, които не се повлияват от приложените лечения в детска и по-късна възраст.
\end{abstract}

Ключови думи: носна обструкция, енурезис ноктурна

\begin{abstract}
We present case of a 20 year old patient with primary enuresis nocturna and nasal obstruction due to a deviated nasal septum, which was operated in our clinic. After a septoplasty, for nine month observation have ceased completely bedwetting patient. Known and described in the literature is the connection between the primary enuresis nosturna and OSA in children. Sleep apnea is common in children with primary nocturnal enuresis and nocturnal enuresis is a common symptom of such obstructive symdrome. No confirmed data on the relationship between isolated difficult nasal breathing without sleep apnea and primary enuresis nocturna. Discussions of the role of nasal obstruction in the case of urinary incontinence, which is not influenced by the treatment in the appended childhood and adulthood.
\end{abstract}

Keywords: nasal obstruction, nocturnal enuresis

\section{Представяне на клиничен случай}

Касае се за двадесетгодишен мъж с анамнеза за нарушено носно дишане от около десет години. Пациентът е лекуван продължително време медикаментозно без успех. След консултация с оториноларинголог е установена девиация на носната преграда и хипертрофия на долни носни конхи, насочен към клиниката ни за оперативно лечение. Няма анамнестични данни за травма на носа в миналото, няма данни за ОСА. Клинично здрав, БМИ 21. Състояние след аденотонзилектомия в детска възраст. При предна риноскопия се установява девиация на носната преграда предимно в каудалната част и хипертрофия на долни носни конхи. Флексибилната назофаринголарингоскопия разкрива свободен назофаринкс, без патологии на фаринкс и ларинкс. Документирана двустранна обструкция при риноманометрия. При попълване на медицинската документация във връзка с хоспитализацията неохотно от страна на майката на пациента бяха споделени анамнестични данни за първична енурезис ноктурна. От петгодишна възраст пациентът е с нощни напикавания, лекувани повече от десет години от педиатри, невролози, уролози, хомеопати и други лечители. Пациентът е бил изследван многократно за органична причина на енурезиса, но такава не е била открита. Подлаган е бил няколкократно на медикаментозна терапия без подобрение. Анамнестично пациентът 
отбелязва периоди на подобрения и влошавания с най-дълъг сух период от месец.

Под ОИА бе направена септопластика и коагулация на долни носни конхи. Пери- и постоперативният период бяха без особености. Наблюдаван в период от 9 месеца, с възстановено носно дишане и направена контролна риноманометрия 6 месеца след оперативната намеса, доказваща нормална проходимост на носната кухина. Периоперативно пациентьт отбелязва един епизод на нощно напикаване. Липсват повече инциденти в деветмесечния следоперативен период.

\section{Обсъждане}

При разглеждането на този клиничен случай възникват няколко въпроса. Има или няма връзка между изолираната назална обструкция и нощното напикаване при деца и възрастни? Случайно стечение на обстоятелствата ли е нашият клиничен случай, или има закономерна връзка между посочените патологии?

Американската педиатрична асоциация определя енурезата като несъзнато и неволно изпускане на урина по време на сън, след като вече е достигната възрастта, при която контролът върху пикочния мехур трябва да е достигнат. Това е възрастта 4 години за момичетата и 5 години за момчетата. Нощното напикаване е по-често срещано при момчета. Енурезата бива първична и вторична. Първична е, когато детето след достигане на посочената възраст редовно или понякога се напикава по време на сън. За вторична се приема тази, при която детето е постигнало контрол, но поради някаква причина е започнало да се изпуска насън. Такава причина може да е захарният диабет, емоционална травма, инфекция на пикочните пътища и др. Социалната значимост на заболяването не подлежи на сьмнение и е свързана с формирането и развитието на нервната система и психиката на детето и се отразява върху всички членове на семейството (1).

$0.5 \%$ е честотата на енурезата при възрастни (18-64 години). За енурезис ноктурна при възрастни се приема нощно изпускане поне веднъж месечно, при изключена органична причина. $50 \%$ от мъжете и $19 \%$ от жените, които съобщават за нощно напикаване, имат пьрвична енурезис ноктурна (2).
Произходът, патофизиологията и причините за възникване на енурезата все още не са напълно уточнени. Съществуват множество теории както за органичния, така и за психогенния ѝ произход. Патомеханизмът е свързан вероятно с полиурията като кардиоваскуларен отговор на негативното налягане при дишане инспириум срещу затворен глотис, както е при обструктивната сънна апнея. В патогенезата участват неврогенни и миогенни компоненти. Неврогенните са свързани с увреждане на централните инхибиторни пътища, а миогенните - със състояния на ацидоза, които увеличават детрузорния контрактилитет и със състояния на хипоксия, намаляващи детрузорния контрактилитет (1).

Първичната енурезис ноктурна е свързвана с обструктивната сънна апнея при деца, с хъркането и затлъстяването при тях - обструктивните проблеми са много чести при деца с първична енуреза и първичната енурезис ноктурна е много чест симптом при обструктивните проблеми на горните дихателни пътища $(4,5)$. В множество статии се обсъжда и доказва тази връзка, която се свързва с хипоксията $(3,4)$. При 6-месечно проследяване след аденотонзилектомия се установява при 40\% пълна липса на инциденти, а при 20\% от децата подобрение на първичната енуреза. Установена е сигнифкантна връзка между нощното напикаване и носната обструкция, дишането през устата в случаи на назофарингеална обструкция при децата $(3,4)$. Изводите, които се правят в медицинската литература, са за връзка между първичната енурезис ноктурна, неповлияваща се на стандартното лечение, и обструктивния синдром при децата с ясно изразено затруднено носно дишане $(5,6)$. В медицинската литература липсват данни за връзка между изолираното нарушено носно дишане и първичната енурезис ноктурна при възрастни. На базата на посочените резултати за връзката на хипоксията при деца с обструктивен синдром на горните дихателни пътища и енурезата може да се направи паралел за такава и при възрастните страдащи от енуреза и обструктивен синдром, свързан с хипоксия, в частност нарушено носно дишане. Затрудненията при възрастните са свързани с премълчаването и прикриването на анамнес- 
тичните данни за енуреза. Множеството въпросителни ни оставят поле за бъдеща работа по този определено неизяснен въпрос в търсене на

\section{Литература:}

1. Славчев Кънчо, Пеев Стоян, Емилова Здравка; Енурезис ноктурна, София 2006

2. Hirasing RA, van Leerdam FJ, Bolk-Bennink L, Janknegt RA. Enuresis nocturna in adults. Scand J Urol Nephrol. 1997 Dec; 31(6): 533-6.

3. Sakellaropoulou AV, Hatzistilianou MN, Emporiadou MN, Aivazis VT, Goudakos J, Markou K, Athanasiadou-Piperopoulou F. Association between primary nocturnal enuresis and habitual snoring in children with obstructive sleep apnoea-hypopnoea syndrome. Arch Med Sci. 2012 Jul 4; 8(3): 521-7. doi: 10.5114/ aoms.2012.28809.

4. Aydil U, Iseri E, Kizil Y, Bodur S, Ceylan A, Uslu S. Aydil U, Işeri E, Kizil Y, Bodur S, Ceylan A, Uslu S. Obstructive upper airway отговори и за честотата на първичната енуреза при възрастни, и за връзката ѝ с изолираното нарушеното носно дишане.

problems and primary enuresis nocturna relationship in pediatric patients: reciprocal study J Otolaryngol Head Neck Surg. 2008 Apr; 37(2): 235-9.

5. Barone JG, Hanson C, DaJusta DG, Gioia K, England SJ, Schneider D. Nocturnal enuresis and overweight are associated with obstructive sleep apnea. Pediatrics. 2009 Jul; 124(1): e53-9. doi: 10.1542/peds. 2008-2805.

6. Thottam PJ, Kovacevic L, Madgy DN, Abdulhamid I. Sleep architecture parameters that predict postoperative resolution of nocturnal enuresis in children with obstructive sleep apnea. Ann Otol Rhinol Laryngol. 2013 Nov; 122(11): 690-4. 